\title{
XENOLITHS OF MANTLE AND METAMORPHIC ROCKS FROM THE DIAMONDIFEROUS V.GRIB PIPE: PETROLOGY AND GENETIC ASPECTS
}

\author{
Andrey Bobrov ${ }^{1}$, Elisey Verichev ${ }^{2}$, Viktor Garanin ${ }^{1}$, Konstantin Garanin ${ }^{1}$ and Galina \\ Kudryavtseva 1 \\ ${ }^{1}$ Moscow State University, Russia; ${ }^{2}$ Arkhangelskgeolrazvedka, Russia
}

\section{INTRODUCTION}

V.Grib kimberlite pipe is a new deposit of diamond after the previously discovered M.Lomonosov deposit in the Arkhangelsk diamond province (Fig. 1). The pipe attracts attention of geologists in several aspects: (1) high content of heavy fraction with prevailing ilmenite; (2) presence of $\mathrm{Cr}-\mathrm{Ti}$ pyrope, picroilmenite, chrome diopside and phlogopite megacrysts; (3) abundance of mantle and crustal (metamorphic) rocks. By these features, V.Grib pipe is similar to typi- cal diamondiferous kimberlite pipes of Yakutia (such as, for example, Udachnaya) and strongly differs from pipes of the M.Lomonosov deposit in which the content of heavy fraction minerals is very low. Chrome spinel is prevailing mineral and picroilmenite is absent in heavy fraction of M.Lomonosov deposit. Summarizing geological, petrological, geochemical and mineralogical data on these deposits, it may be concluded that similarly to South Africa and Yakutia there are two types of diamondiferous bodies with their specific features in the Arkhangelsk diamond province (Garanin et al., 2001).

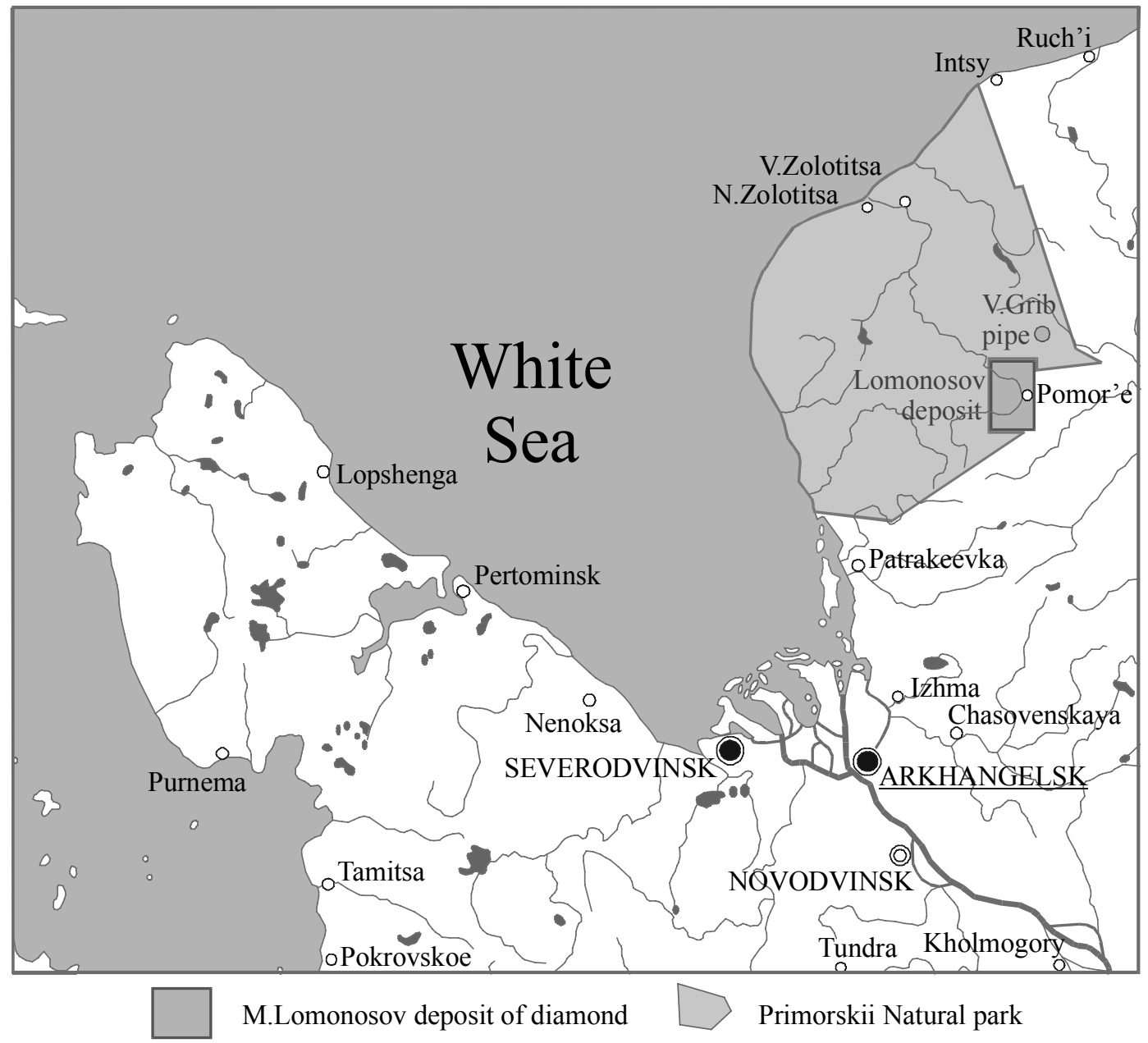

Fig. 1. Location of V.Grib kimberlite pipe and M.Lomonosov deposit of diamond within the Arkhangelsk area in Russia (Krotkov et al., 2001) 
Our paper contains the results of the detailed study of mantle and metamorphic xenoliths from V.Grib kimberlite pipe. These new data have a great interest for reconstruction of the cross-section of the earth crust and upper mantle in the Arkhangelsk diamond province. Xenogenic material in this pipe comprises fragments of siltstone, claystone and xenoliths of various deep-seated rocks. The content of mantle xenoliths is significantly higher than in all other known pipes of the Arkhangelsk diamond province (Bogatikov et al., 1999; Krotkov et al., 2001). The following varieties have been distinguished among the studied mantle xenoliths: spinel and garnet peridotite (lherzolite and harzburgite), pyroxenite (websterite) and eclogite with transitions to almost monomineral garnet rocks. In addition, megacrysts mainly of garnet and clinopyroxene are met. Among crustal rocks we have distinguished garnet-containing schist (eclogite-like rocks) transitional to eclogite.

\section{PETROLOGY AND MINERALOGY}

We have studied 15 xenoliths from V.Grib kimberlite pipe. These rocks have oval, rounded, loaf-like, rarely angular shape. The sizes of studied xenoliths vary from first $\mathrm{mm}$ to 5 $\mathrm{cm}$. Table 1 contains data on mineral composition of xenoliths.

Peridotite is presented by rocks of two depth facies: garnet and spinel. The content of garnet in these rocks varies from 5 to 25 vol.\%; olivine, from 10 to 65 vol.\%; orthopyroxene, from 10 to 15 vol.\%. The content of clinopyroxene reaches $25 \mathrm{vol.} \%$. In some cases this mineral is not found that allows us to attribute the rock to harzburgite. In spinel peridotite the content of chrome spinel does not exceed 5 vol.\%. Minor minerals are presented mainly by phlogopite forming brown scales near the contact with kimberlite matrix. Spinel and ilmenite have been determined among accessory minerals.

The rocks are fine-grained, equigranular, rarely porphyry (phenocrysts with a size of up to $9 \mathrm{~mm}$ are presented by garnet. Some rocks are characterized by specific textures of olivine replacement by serpentine. In addition to serpentine, secondary calcite and chlorite are met.

Garnet in rocks forms uneven, quite large grains strongly shared, and often cut by a system of parallel cracks usually typical for cataclastic rock types. Kelyphitic rims are observed on some garnet grains, and these rims consist of greenish-brown chlorite-phlogopite aggregate with small hercynite grains.

Pyroxenite rocks are presented by a xenolith of garnet websterite (Sample 93-247). It is characterized by complete absence of olivine and up to 40 vol.\% of secondary calcite replacing rock-forming minerals probably as a result of the

\section{Table 1: Mineral composition of xenoliths from V.Grib kimberlite pipe}

$\begin{array}{ll}\text { Sample } & \text { Rock } \\ 93-236 & \text { Garnet wherlite } \\ 93-268 & \text { Garnet harzburgite } \\ 73-215 & \text { Garnet Iherzolite } \\ 53-467 & \text { Garnet Iherzolite } \\ 93-247 & \text { Garnet websterite } \\ 90-328 & \text { Chrome spinel Iherzolite } \\ 73-230 & \text { Garnet clinopyroxenite } \\ 93-265 & \text { Eclogite } \\ 53-387 & \text { Garnet rock } \\ 103-152 & \text { Garnet rock } \\ 93-230 & \text { Pyroxene-garnet schist } \\ 93-232 & \text { Garnet-pyroxene- } \\ & \text { plagioclase schist } \\ 53-471 & \text { Pyroxene-biotite } \\ & \text { schist with garnet } \\ 73-247 & \text { Garnet-pyroxene- } \\ & \text { plagioclase schist } \\ 53-387 & \begin{array}{l}\text { Pyroxene-plagioclase- } \\ \text { garnet schist }\end{array}\end{array}$

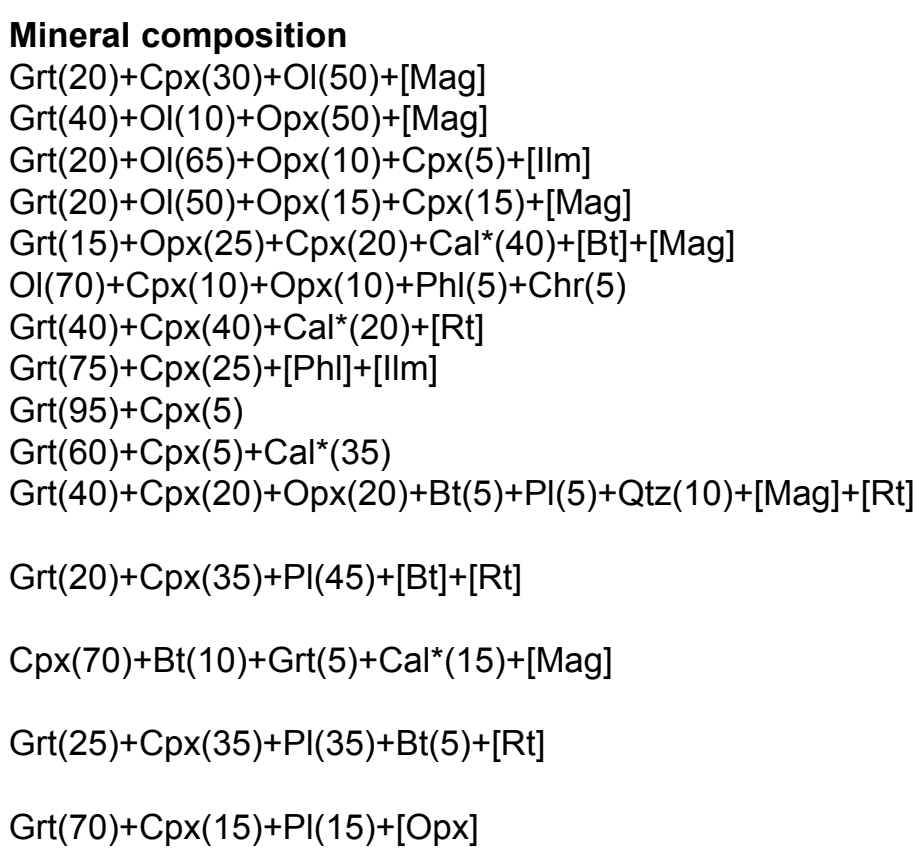

Content of mineral in rock (vol.\%) is indicated in parentheses; minor and accessory minerals (less than 1\%) are presented in square brackets; * - secondary minerals. Ol - olivine; Grt - garnet; Opx - orthopyroxene; Cpx - clinopyroxene; Phl - phlogopite; Bt - biotite; Pl - plagioclase; Cal - calcite; Chr - chrome spinel; Rt - rutile; Ilm - ilmenite; Mag - magnetite 
kimberlite melt influence. Carbonatization is also typical for eclogite, garnet rocks and crustal schist. Orthopyroxene in this rock is presented by practically pure enstatite.

Eclogite rocks are related to rutile and ilmenite types; the content of garnet in them varies from 40 to $75 \mathrm{vol} \% \%$ and higher. When the content of omphacite is less than $5 \%$, the rock is attributed to garnetite. Phlogopite has been distinguished as a minor mineral in one of the rocks. Eclogite rocks are fine-grained, massive.

Xenoliths of crustal rocks contain plagioclase (5-45 vol.\%) and garnet (5-70 vol.\%), and also pyroxenes, biotite, quartz, magnetite rutile are met; the content of these minerals strongly varies in different samples (Table 1). The rocks are granoblastic that is typical for metamorphic types of xenoliths, their texture is massive with elements of schistosity. Coronated rims of diopside-quartz composition are observed between omphacite and plagioclase.

\section{MICROPROBE ANALYSIS}

Compositions of the minerals from xenoliths of V.Grib kimberlite pipe have been studied using the electron microscope JSM-820 with AN-10000 analyser. Our special attention has been paid to garnet and clinopyroxene; these minerals may provide evidence for the conditions of mantle rock formation and metasomatic processes. Using the classification of V.Garanin with co-authors (1991), all minerals have been attributed definite parageneses of deep-seated rocks.

Garnets from studied lherzolite are low-chromium (3-4 wt.\% $\mathrm{Cr}_{2} \mathrm{O}_{3}$ ) and contain 4-5 wt.\% CaO. Garnets from megacrysts differ from minerals of ultrabasic rocks by higher content of titanium (0.8-1 wt.\%TiO2), iron (8.4-8.8 wt.\% FeO), that provides evidence for the presence of two large types of ultrabasic rocks: typical peridotite, lherzolite and pyroxenite, and specific association of megacrysts (Cr-Ti garnet, chrome diopside, picroilmenite and phlogopite). The latter association provided the age of rock by phlogopite ( $\sim 990 \mathrm{Ma})$. Probably this mineral assemblage typical for the pegmatitic stage in the evolution of mantle rocks is younger than the most ultrabasic rocks (equigranular and shared lherzolite and pyroxenite). Eclogite garnets may be related to iron-magnesium varieties of these rocks (6-14 wt.\% MgO; 16-25 wt.\% $\mathrm{FeO}$; 5.5-7.0 wt.\% $\mathrm{CaO}$; up to 0.40 wt.\% Na2O). According to the database on garnet from V.Grib pipe ( $\sim 500$ analyses) this assemblage is only $10 \%$ from all types of mantle rocks. It is necessary to mention that xenoliths of aluminous and calcium eclogite are practically absent in the Arkhangelsk diamond province. This fact may provide evidence for low activity of subduction during the craton formation beneath

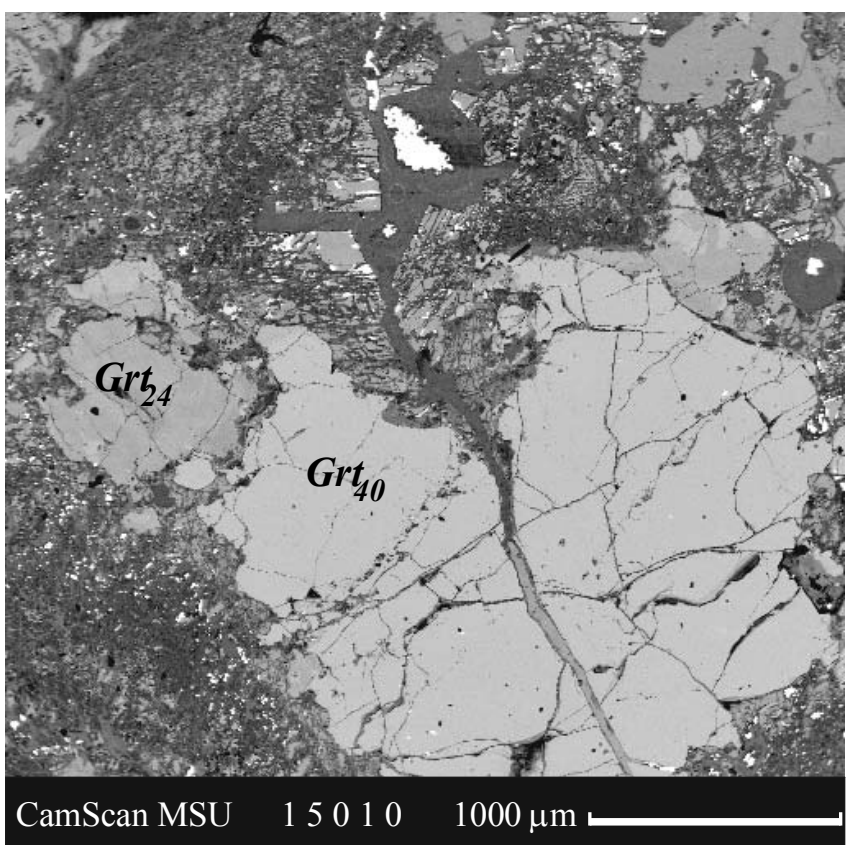

Fig. 2. Back-scattered electron image of large garnet crystal $\left(\mathrm{Grt}_{40}\right)$ surrounded by pyrope-rich garnets $\left(\mathrm{Grt}_{24}\right)$ in garnet pyroxenite from V.Grib pipe. Sample 73-230

Table 2: Compositions of zoned garnets from garnet pyroxenite (73-230) and eclogite (93265) of V.Grib kimberlite pipe

$\begin{array}{lllll}\text { Sample } & \mathbf{7 3 - 2 3 0} & & \mathbf{9 3 - 2 6 5} & \\ & \mathbf{C} & \mathbf{R} & \mathbf{C} & \mathbf{R} \\ \mathrm{SiO} 2 & 40.47 & 41.87 & 39.34 & 40.6 \\ \mathrm{TiO} 2 & - & 0.39 & 0.32 & - \\ \mathrm{Al} 2 \mathrm{O} 3 & 22.29 & 22.53 & 21.37 & 22.61 \\ \mathrm{Cr} 2 \mathrm{O} 3 & - & 0.35 & - & - \\ \mathrm{FeO} & 17.06 & 10.51 & 17.68 & 13.78 \\ \mathrm{MnO} & 0.32 & 0.48 & 0.47 & 0.60 \\ \mathrm{MgO} & 13.61 & 19.07 & 10.13 & 15.64 \\ \mathrm{CaO} & 5.95 & 4.56 & 10.34 & 6.51 \\ \text { Total } & 99.70 & 99.76 & 99.65 & 99.74\end{array}$

the Arkhangelsk diamond province.

In some cases we observe zonation of garnet and clinopyroxene crystals (both direct and inverse types). Fig. 2 and Table 2 demonstrate broad range of garnet zonation in garnet clinopyroxenite and eclogite from V.Grib pipe. From central to outer parts of crystals the composition of garnet provides transitions from pyroxenite to peridotite (73-230) and from eclogite to pyroxenite (93-265). The diversity of garnet composition is presented in Ca-Mg-Fe diagram (Fig. 3) on which garnet-clinopyroxene parageneses from the studied rocks 


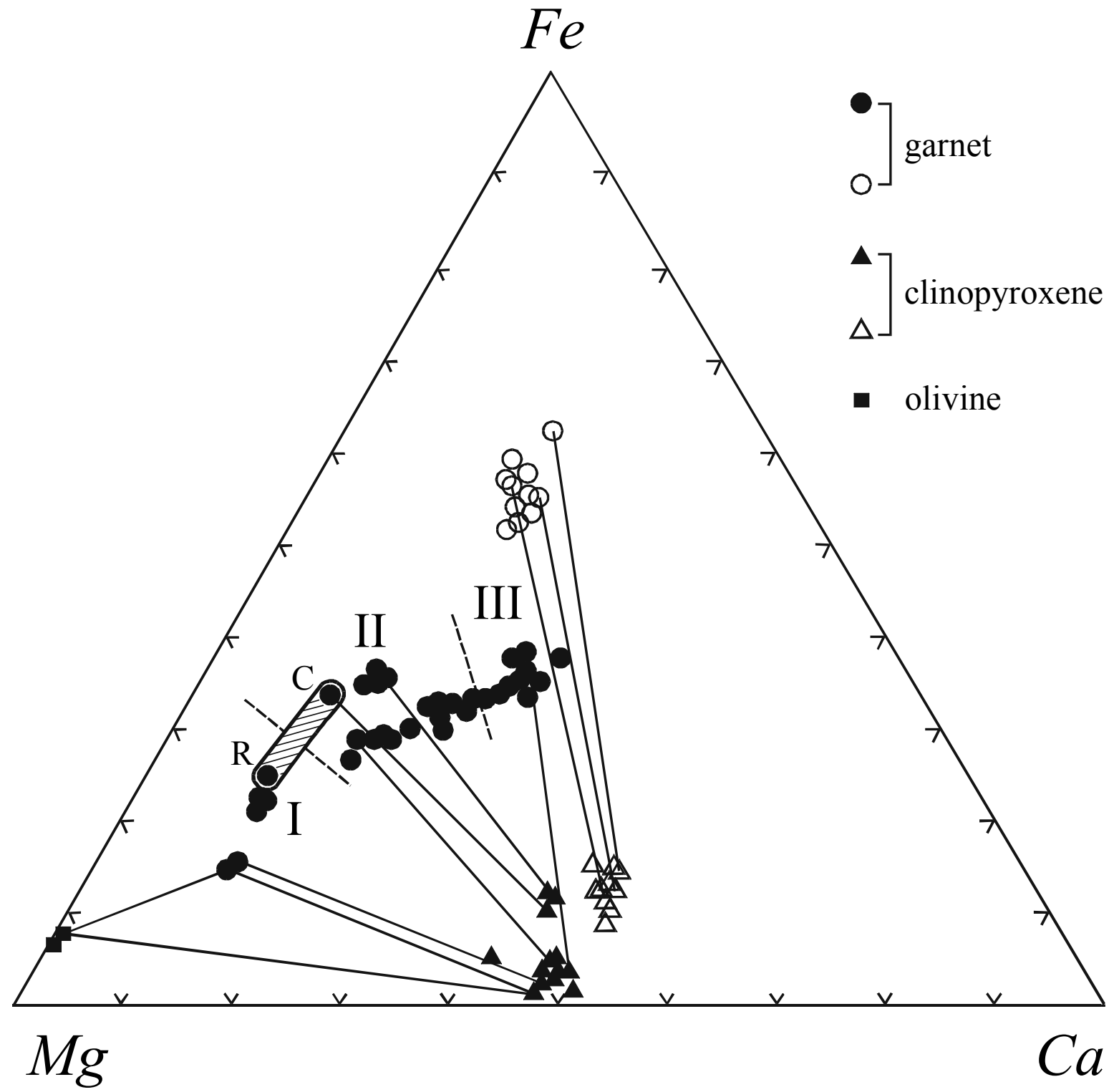

Fig. 3. Mineral parageneses of mantle (full symbols) and crustal (open symbols) rocks from V.Grib kimberlite pipe. The chemistries of garnet and clinopyroxene characterize the compositions of their parental rocks: (I) pyrope peridotite; (II) garnet pyroxenite; (III) eclogite and eclogite-like rocks. The shaded stripe shows the composition trend in a zoned garnet grain from the core (C) to rim (R), which corresponds to the transition from pyroxenite to peridotite

from V.Grib pipe are demonstrated. According to the garnet composition all studied rocks have been divided in to pyrope peridotite (I), garnet pyroxenite (II) and eclogite (III). Garnets from metamorphic (crustal) rocks (opened circles) are also presented in Fig. 3.

\section{PT-PARAMETERS OF ROCK FORMATION}

PT-conditions of the rock formation for mantle rocks have been calculated by garnet-clinopyroxene parageneses using concordant system of thermometers and barometers (Nikitina, 1993). We have obtained the following data: pyrope peridotite has been formed at $\mathrm{T}=1000-1250^{\circ} \mathrm{C}, \mathrm{P}=38$ -
46 kbar; eclogite, at $\mathrm{T}=950-1050^{\circ} \mathrm{C}, \mathrm{P}=35-39 \mathrm{kbar}$, that provides evidence for the formation of rocks near the thermodynamic boundary of graphite-diamond transition.

Mineral associations of crustal (eclogite-like) rocks provide evidence for their formation within the garnet-pyroxene-plagioclase facies of metabasite metamorphism $\left(\mathrm{T}=800-900^{\circ} \mathrm{C}\right.$, $\mathrm{P}=6-9$ kbar).

\section{CONCLUSIONS}

Thus, it may be concluded that V.Grib pipe contains xenoliths of various mantle (peridotite, pyroxenite, eclogite) and 
crustal rocks. The studied rocks have signs of mantle metasomatismthat is reflected in the presence of thin kelyphite rims on garnets and modified outer parts of clinopyroxene grains. According to the database on garnet from V.Grib pipe ( $\sim 500$ analyses) garnet of the eclogite assemblage (iron-magnesium type) is only $10 \%$ from all types of mantle rocks. That provides evidence for prevalence of ultrabasic rocks (including ilmenite varieties) in the mantle cross-section beneath the pipe. The discrete process of the formation of mantle rocks is evident, that results from the time gap between the crystallization of the main group of rocks (peridotite, pyroxenite, eclogite) and rocks of pegmatitic type (assemblage of megacrysts). In addition to that, xenoliths of aluminous and calcium eclogite are absent, that provides evidence for low activity of subduction during the craton formation beneath the Arkhangelsk diamond province. This is a characteristic feature of the upper mantle cross-section beneath the Arkhangelsk diamond province.

\section{ACKNOWLEDGMENTS}

Our study was supported by the Russian Foundation for Basic Research (project no. 01-05-64508).

\section{REFERENCES}

Bogatikov, O.A., Garanin, V.K., Kononova V.A. et al., 1999. Arkhangelsk diamond province (geology, petrography, miner- alogy and geochemistry). Moscow Univ., Moscow (in Russian).

Garanin, V.K., Kudryavtseva, G.P., Marfunin, A.S. et al., 1991. Inclusions in diamond and diamondiferous rocks. Moscow Univ., Moscow (in Russian).

Garanin, V.K., Kudryavtseva, G.P., Posukhova, T.V. et. al., 2001. Two types of diamondiferous kimberlites in the Arkhangelsk province. Geologiya i razvedka. 4, 36-50 (in Russian).

Krotkov, V.V., Kudryavtseva, G.P., Bogatikov, A.A. et al., 2001. New technologies of the diamond deposit exploration. GEOS, Moscow (in Russian).

Nikitina, L.P., 1993. Concordant system of thermometers and barometers for basic and ultrabasic rocks and reconstruction of thermal regimes in mantle by xenoliths in kimberlites. Zap. Miner. Soc. 22, 5, 6-19 (in Russian).

Contact: AV Bobrov, Dept. of Petrology, Geological Faculty, Moscow State University, Leninskie gory, Moscow, 119992 Russia, E-mail: archi@geol.msu.ru 